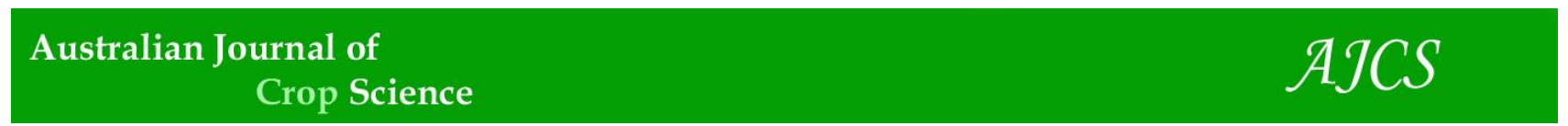

AJCS 14(10):1541-1548 (2020)

ISSN:1835-2707

doi: 10.21475/ajcs.20.14.10.p1485

\title{
Can different soil fertilization regimes modify soil fauna to interfere in maize grain yield?
}

\author{
Ana Luiza Privado Martins ${ }^{1 *}$, Glécio Machado Siqueira ${ }^{2}$, Emanoel Gomes de Moura ${ }^{3}$, Raimunda Alves \\ Silva ${ }^{4}$, Francisca Ferreira Farias ${ }^{4}$, Alana das Chagas Ferreira Aguiar ${ }^{5}$ \\ ${ }^{1}$ Federal Institute of Maranhão, Povoado Poraquê, Zona Rural s/n, 65400-000, Codó - MA, Brazil \\ ${ }^{2}$ Geoscience Department - Federal University of Maranhão, Av. dos Portugueses 1966, Bacanga, 65080-805, São \\ Luís - MA, Brazil \\ ${ }^{3}$ Graduate Program in Agroecology, State University of Maranhão, 65054-970, São Luís - MA, Brazil \\ ${ }^{4}$ Federal University of Maranhão, Av. dos Portugueses 1966, Bacanga, 65080-805, São Luís - MA, Brazil \\ ${ }^{5}$ Biology Department - Federal University of Maranhão, Av. dos Portugueses 1966, Bacanga, 65080-805, São Luís - \\ MA, Brazil
}

*Corresponding author: ana.Ipm@ifma.edu.br

\begin{abstract}
Soil fauna activities transform the soil, but soil organisms are also influenced by changes in the land. We hypothesize that different soil fertilization regimes modify soil fauna and in this way affect maize grain yield. The aim of this study was to evaluate the effects of different soil fertilization regimes on the structure of the soil fauna and the association between these organisms and the maize grain yield. The experiment was conducted in Maranhão State (Brazil), in an alley crop system which was divided into 32 plots of $4 \times 10 \mathrm{~m}$, with four replicates and the following treatments: Gliricidia sepium - gliricidia (G), potassium (K), humic acid (HA), humic acid + potassium $(H A+K)$, potassium + gliricidia $(K+G)$, humic acid + potassium + gliricidia $(H A+K+G)$, humic acid + gliricidia $(H A+$ G) and uncovered soil (US). Soil fauna dominance, abundance, richness, Shannon-Wiener diversity index, and Pielou evenness index and maize grain yield were determined. Fertilization with humic acid and potassium caused the dominance of isopods. The dominance of ants was also related to soil potassium (K treatment). The only taxon associated with yield was Araneae. Although fauna abundance did not show differences between treatments, it was related to yield. This study does not confirm the hypothesis that different soil fertilization regimes affect soil fauna and consequently influence maize grain yield. Nevertheless, we confirm that maize grain yield may be improved by the presence of specific groups and by the increased abundance of soil fauna.
\end{abstract}

Keywords: abundance; Araneae; detritivores; ecological index; legume; predators; principal component analysis; soil quality. Abbreviations: G_Gliricidia sepium; HA_humic acid; HA + G_humic acid + gliricidia; HA + K_humic acid + potassium; HA + K + G_humic acid + potassium + gliricidia; K_potassium; K + G_potassium + gliricidia; US_uncovered soil.

\section{Introduction}

Soil fauna provides beneficial services both in situ and in the surrounding environment. For example, soil fauna enhances soil drainage, creates passages for plant roots and aerates the soil (Huguenin et al., 2006). In addition, soil fauna takes an active part in the recycling of nutrients back into the soil through the decomposition of plant debris (Wong et al., 1992). Höfera et al. (2001) conclude that these organisms provide valuable ecosystem services that sustain soil quality and vegetable growth.

There is a mechanism of interaction between litter composition and the soil fauna community, as these animals can alter the effect that litter quality exerts on decomposition. This process is important for site fertility (Carrillo et al., 2011). Zhang et al. (2015) suggest that the role of soil fauna in regulating litter decomposition in different ecosystems is essential. Their results showed a $35 \%$ slower decomposition rate of plant litter, on average, when soil fauna is absent.
The activities of soil fauna modify the physical structure of soil and hence regulate the rates of movement of nutrients, water and gases. For example, these organisms lead to macropore development, which has various consequences, such as increased water absorption and therefore reduced run-off and erosion, reduced waterlogging, and changes in the distribution of water in the soil profile that may alter the competitive balance between plants with different rooting depths (Erouissi et al., 2011; Sanginga et al., 1992).

In this context, understanding the influence of soil characteristic on the soil fauna is also very relevant (Erouissi et al., 2011). For Sanabria et al. (2014), soil biodiversity is very sensitive to land changes and is an important regulator of key soil processes. Previous studies have detected that the composition and diversity of soil fauna communities are influenced by changes in soil organic matter and fertility. Then, variations in these communities are related to the fertilization regime. Although fertilizer use is important to 
improved crop yield, it alters soil properties and changes the soil fauna structure (Zhu and Zhu, 2015). Thus, these animals can be used as edaphic quality indicators, since there is a relationship between their community structure and the processes occurring in the soil (Guimarães et al., 2017; Paoletti et al., 1996). Siqueira et al. (2014) assert that there are some advantages to the use of soil fauna to measure soil quality compared to other biological methods. Furthermore, it is possible to identify functional groups within the edaphic fauna that are more sensitive to changes in land (Hu et al., 1997; Tao et al. 2016).

Fertilizers also alter abundance of edaphic fauna, affecting the environment of these organisms and changing the crop yield. Soil fauna feeding also alter maize yield (Jiang et al., 2015). Huguenin et al. (2006) argued that edaphic fauna increases agricultural production. Soil engineers, for example, affect plant productivity, regulating the stability of soil biota (Kilowasid et al., 2012).

Therefore, our hypothesis is that the different soil fertilization regimes modify soil fauna and thus interfere in the maize grain yield. The aim of this study was to evaluate the effects of different soil fertilization regimes on the structure of soil fauna and their association with maize yield.

\section{Results}

Composition, abundance, dominance and ecological indexes of soil fauna

A total of 3,629 individuals from the soil fauna were collected during the sample period. They were distributed in 32 taxa, with a maximum of 25 taxa at $\mathrm{HA}+\mathrm{K}$ and a minimum of 17 at $\mathrm{HA}+\mathrm{K}+\mathrm{G}$. The largest soil fauna community was found at $\mathrm{HA}+\mathrm{K}$ (698 individuals), and the smallest was collected at $\mathrm{HA}+\mathrm{K}+\mathrm{G}$ (345 individuals) (Table 1). The taxa exhibiting the greatest number of specimens in total were Formicidae, Isopoda, Diplura, Coleoptera, Orthoptera and Araneae, together accounting for $92.7 \%$ of the collected organisms.

Isopoda was the group with the largest mean number of individuals per treatment $(76.7 \pm 55.9$ at $\mathrm{HA}+\mathrm{K})$. Significant differences were detected between this taxon and the others into this treatment $(p<0.05)$. The mean number of Formicidae was significantly larger than that of other groups at $K(34.5 \pm 12.9)(p<0.05)$ (Fig. 1).

The Shannon indexes were significantly higher at $G$ and $H A$ than at $K+G$ and $H A+G(p<0.05)$. The Pielou index was significantly higher at $G$ than at $H A+K, K+G$ and $H A+G(p<$ $0.05)$. The richness and abundance showed no significant difference between treatments $(p>0.05)$ (Table 2).

In the cluster analysis, the treatments with Euclidian distances between 20 and 30 were classified into three groups, i.e., (1) $K+G, H A+K$, (2) $H A+G, H A+K+G, U S$, $H A$, $K$ and (3) $G$. Group 1 includes treatments in which Isopoda stood out, group 2 contains mainly Formicidae, and group 3 isolated the only treatment in which Diplura predominated (Fig. 2).

\section{Maize grain yield}

The maize grain yield was significantly higher for all treatments that received gliricidia $(G, K+G, H A+K+G$ and $H A+G)$ than for treatments that did not receive it $(H A+K, K$, HA and US) $(p<0.05)$ (Table 3).

\section{Relations between soil fauna and maize grain yield}

In the PCA that associated yield with taxonomic groups, $53.54 \%$ of the variation was explained by its two main components. Axis 1 was mainly associated with Coleoptera and Formicidae, while axis 2 was associated with Araneae and Diplura. Yield showed a strong positive correlation with Araneae (Fig. 3a).

In the PCA that associated yield with ecological indexes and abundance, the two main components explained $78 \%$ of the variation. Axis 1 was mainly associated with Pielou index and Shannon index, while axis 2 was associated with richness and abundance. The only positive correlation found was between yield and abundance (Fig. 3b).

\section{Discussion}

In this research, the number of taxa and the total number of individuals in the soil fauna varied between treatments. Siqueira et al. (2014) and Blanchart et al. (2006) affirm that soil invertebrate communities vary according to the way that land is used. In study by Cluzeau et al. (2012), land uses and certain agricultural practices caused great differences in the populations of these organisms.

Isopoda stood out among all the groups, especially at the $\mathrm{HA}+\mathrm{K}$ treatment. For Podgaiski et al. (2011), isopods are related to the kind of agricultural crop and the land uses. According to Bahadur et al. (2014), potassium is one of the soil constituents that is most important for plant growth and development. For Bünemann et al. (2006), humic substances also increase plant growth. Since isopods are general detritivores, they can feed upon the foliage of seedlings, and their mandibles are capable of considerable fragmentation of decaying vegetable matter (Coleman et al., 2004). This may have favoured a faster reproduction of this group, which probably had access to plant remains due to fertilization with humic acid and potassium.

Formicidae stood out in the $\mathrm{K}$ treatment. Coleman et al. (2004) note that activities of this group reduce the abundance of predators, as was verified in the present study. This taxon is sensitive to changes in land use and to disturbances (Andersen et al., 2002). Because of this, ants may be useful to evaluate the biological status of the cultivated stands. They can also have significant influences on soil and ecosystem functioning, and thus their populations reflect key ecological processes within agroecosystems (Lavelle et al., 2006).

In a study performed in Colombia, ant communities were greatly influenced by soil alterations (Sanabria et al., 2014). According to Siqueira et al. (2014), soil cover is one of the factors affecting the organic matter and litter production in agricultural fields and thus the food availability for soil fauna. In an experiment conducted with tillage and crop residue retention and that included Leguminosae, ants were one of the most abundant groups (Paul et al., 2015). However, in our research, we did not note a specific increase in the Formicidae community under treatments with gliricidia. Zörb et al. (2014) report that potassium enhances the soil structure, for example, the water-holding capacity. This function of potassium may have favoured the presence and activity of the ants, which also improve soil structure, since according to Paul et al. (2015), they are considered engineers. The sum of these factors may have caused the growth of this population in the area fertilized with potassium. 
Table 1. Total number of individuals collected by pitfall traps during a week per taxonomic group studied. G: gliricidia, HA $+\mathrm{K}$ : humic acid + potassium, K + G: potassium + gliricidia, K: potassium, HA + K + G: humic acid + potassium + gliricidia, HA + G: humic acid + gliricidia, HA: humic acid, US: uncovered soil.

\begin{tabular}{|c|c|c|c|c|c|c|c|c|}
\hline & $\mathrm{G}$ & $\mathrm{HA}+\mathrm{K}$ & $\mathrm{K}+\mathrm{G}$ & $\mathrm{K}$ & $\mathrm{HA}+\mathrm{K}+\mathrm{G}$ & $\mathrm{HA}+\mathrm{G}$ & $\mathrm{HA}$ & US \\
\hline Acari & 3 & 1 & & 1 & & & 2 & \\
\hline Araneae & 28 & 13 & 18 & 19 & 13 & 14 & 14 & 6 \\
\hline Araneae (cocoon) & & & & & & 1 & & \\
\hline Archaeognatha & & & & & & & & 1 \\
\hline Auchenorrhyncha & 2 & 2 & 3 & 3 & 2 & 2 & 3 & 2 \\
\hline Blattodea & 2 & 3 & 2 & 2 & & 1 & 1 & 3 \\
\hline Chilopoda & & 2 & 1 & 1 & 2 & 2 & 1 & \\
\hline Coleoptera & 25 & 67 & 30 & 61 & 40 & 35 & 73 & 56 \\
\hline Coleoptera (larva) & & 7 & 5 & 2 & 1 & & 3 & \\
\hline Dermaptera & 2 & & 1 & & & & 1 & 1 \\
\hline Diplopoda & & 4 & 3 & & 1 & & & 4 \\
\hline Diplura & 126 & 107 & 144 & 43 & 69 & 73 & 60 & 51 \\
\hline Diptera & 3 & 1 & 4 & 6 & 2 & 3 & 4 & 3 \\
\hline Diptera (larva) & 2 & 1 & & & & 9 & 2 & \\
\hline Entomobryomorpha & 4 & 1 & 1 & & 4 & 1 & 8 & 3 \\
\hline Formicidae & 90 & 146 & 120 & 138 & 122 & 197 & 153 & 114 \\
\hline Heteroptera & & 1 & 1 & 2 & 3 & & 1 & 1 \\
\hline Hymenoptera & 5 & 5 & 3 & 2 & 7 & 3 & 3 & 3 \\
\hline Isopoda & 77 & 307 & 210 & 69 & 62 & 102 & 47 & 89 \\
\hline Isoptera & & 2 & 3 & 2 & 2 & & 5 & 1 \\
\hline Lepidoptera (larva) & & 1 & 3 & 1 & 1 & 3 & 2 & 1 \\
\hline Neuroptera (larva) & & & & & & & & 1 \\
\hline Opillionida & 4 & 1 & & 2 & & & 2 & \\
\hline Orthoptera & 23 & 20 & 12 & 18 & 13 & 11 & 17 & 21 \\
\hline Phasmatodea & & 1 & & & & & & 1 \\
\hline Poduromorpha & 7 & 1 & & & & & & 6 \\
\hline Pseudoscorpionida & & 1 & & & & & & \\
\hline Sternorrhyncha & 2 & 2 & & 1 & 1 & 2 & 5 & 1 \\
\hline Symphyla & 1 & & & & & & & \\
\hline Thysanura & & & & & & 1 & & \\
\hline Trichoptera & & 1 & & & & 1 & & 1 \\
\hline Pupa & & & & & & 1 & 4 & \\
\hline Total & 406 & 698 & 564 & 373 & 345 & 462 & 411 & 370 \\
\hline
\end{tabular}

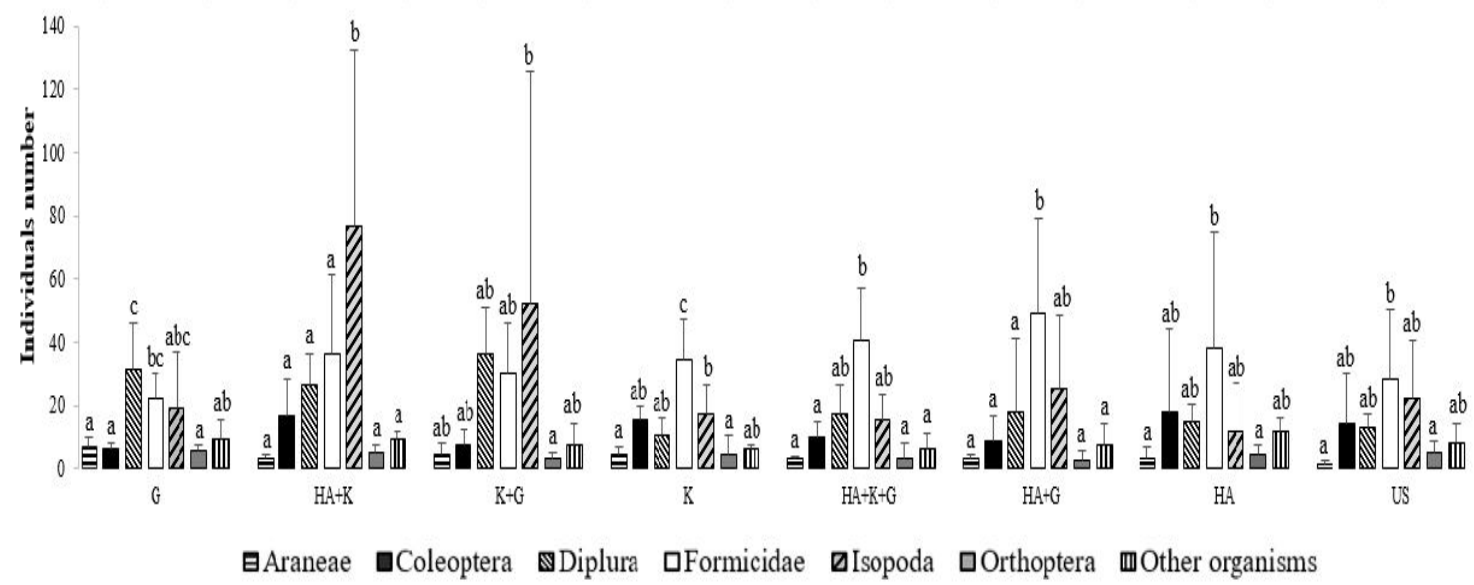

Fig 1. Dominance of taxonomic groups of soil fauna (mean \pm standard deviation) per treatment. Taxa with distinct letters within the same treatment are significantly different (ANOVA with Duncan's test, $p<0.05$ ). G: gliricidia, HA + K: humic acid + potassium, K + G: potassium + gliricidia, K: potassium, HA + K +G: humic acid + potassium + gliricidia, HA + G: humic acid + gliricidia, HA: humic acid, US: uncovered soil. 
Table 2. Shannon index $\left(H^{\prime}\right)$, Pielou index $\left(J^{\prime}\right)$, total richness $(\mathrm{S})$ and abundance $(\mathrm{A})$ of soil fauna communities at different treatments (mean \pm standard deviation). Distinct letters within the same column indicate significant differences $(p<0.05)$. G: gliricidia, HA + K: humic acid + potassium, K + G: potassium + gliricidia, K: potassium, HA + K + G: humic acid + potassium + gliricidia, HA + G: humic acid + gliricidia, HA: humic acid, US: uncovered soil, std. dev.: standard deviation.

\begin{tabular}{lllll}
\hline Treatment & $H^{\prime} \pm$ std.dev & $J^{\prime} \pm$ std.dev & S \pm std.dev & A \pm std.dev \\
\hline G & $1.843 \pm 0.079 \mathrm{a}$ & $1.796 \pm 0.160 \mathrm{a}$ & $11 \pm 2.7 \mathrm{a}$ & $14.5 \pm 5.5 \mathrm{a}$ \\
$\mathrm{HA}+\mathrm{K}$ & $1.593 \pm 0.232 \mathrm{ab}$ & $1.430 \pm 0.203 \mathrm{~b}$ & $13 \pm 0.8 \mathrm{a}$ & $24.9 \pm 11.7 \mathrm{a}$ \\
$\mathrm{K}+\mathrm{G}$ & $1.446 \pm 0.129 \mathrm{~b}$ & $1.473 \pm 0.257 \mathrm{~b}$ & $10.2 \pm 3.2 \mathrm{a}$ & $20.1 \pm 11.1 \mathrm{a}$ \\
$\mathrm{K}$ & $1.734 \pm 0.181 \mathrm{ab}$ & $1.669 \pm 0.198 \mathrm{ab}$ & $11 \pm 0.8 \mathrm{a}$ & $13.3 \pm 2.4 \mathrm{a}$ \\
$\mathrm{HA}+\mathrm{K}+\mathrm{G}$ & $1.594 \pm 0.301 \mathrm{ab}$ & $1.672 \pm 0.160 \mathrm{ab}$ & $9.2 \pm 2.7 \mathrm{a}$ & $12.3 \pm 3.9 \mathrm{a}$ \\
$\mathrm{HA}+\mathrm{G}$ & $1.384 \pm 0.309 \mathrm{~b}$ & $1.406 \pm 0.178 \mathrm{~b}$ & $10.2 \pm 4.3 \mathrm{a}$ & $16.5 \pm 8.8 \mathrm{a}$ \\
$\mathrm{HA}$ & $1.831 \pm 0.189 \mathrm{a}$ & $1.723 \pm 0.225 \mathrm{ab}$ & $12 \pm 2.9 \mathrm{a}$ & $14.7 \pm 12.4 \mathrm{a}$ \\
US & $1.699 \pm 0.210 \mathrm{ab}$ & $1.714 \pm 0.151 \mathrm{ab}$ & $10.7 \pm 4.6 \mathrm{a}$ & $13.2 \pm 9.6 \mathrm{a}$ \\
\hline
\end{tabular}

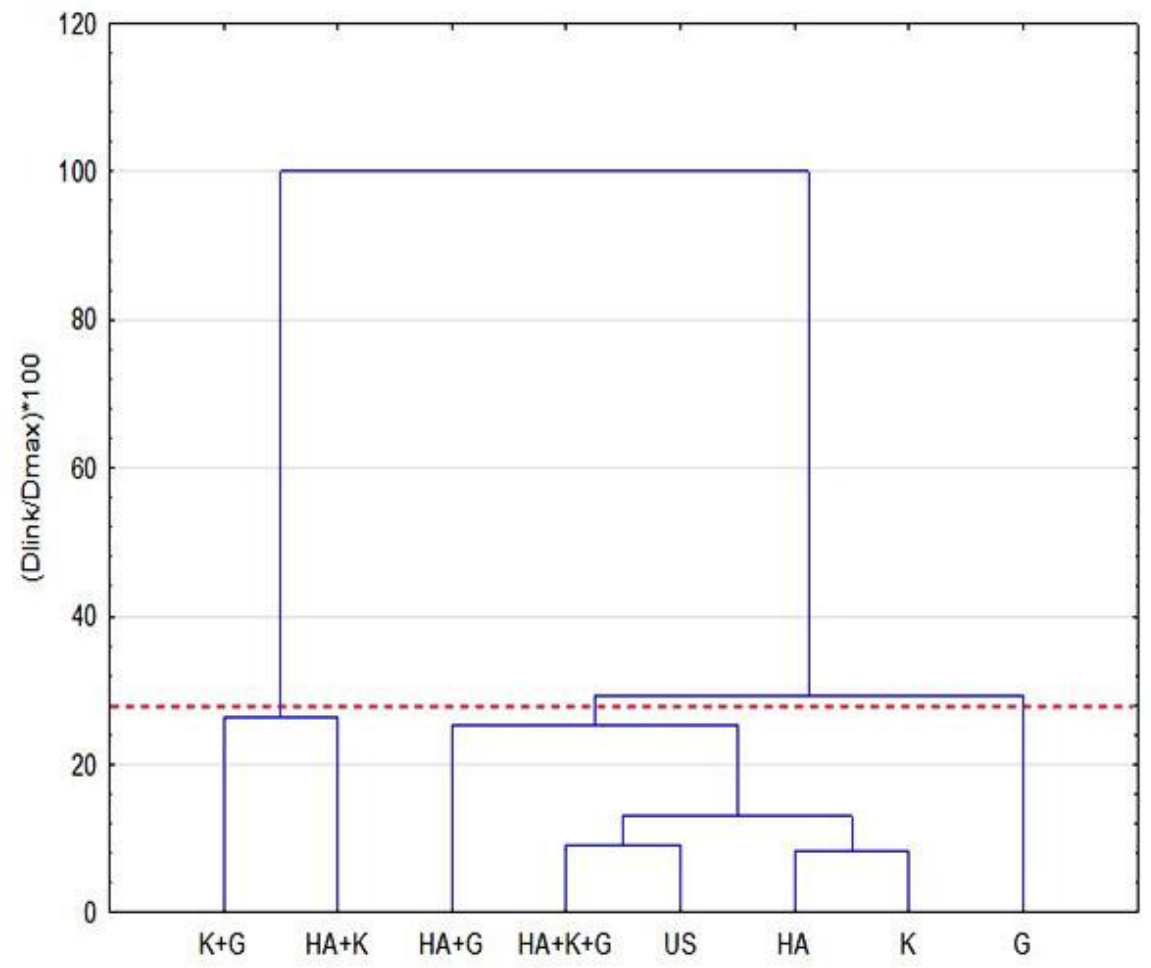

Fig 2. Dendrogram resulting from hierarchical cluster analysis with the formation of groups based on the Euclidean distance of the taxonomic groups of soil fauna. $\mathrm{K}+\mathrm{G}$ : potassium + gliricidia, HA + K: humic acid + potassium, HA + G: humic acid + gliricidia, HA + K + G: humic acid + potassium + gliricidia, US: uncovered soil, HA: humic acid, K: potassium, G: gliricidia.

Table 3. Maize grain yield after different treatments. Distinct letters indicate significant differences (ANOVA with Duncan's test, $p<$ 0.05). G: gliricidia, HA + K: humic acid + potassium, K + G: potassium + gliricidia, K: potassium, HA + K + G: humic acid + potassium + gliricidia, HA + G: humic acid + gliricidia, HA: humic acid, US: uncovered soil.

\begin{tabular}{ll}
\hline Treatment & Grain yield $\left(\mathrm{Mg} \mathrm{ha}^{-1}\right)$ \\
\hline $\mathrm{G}$ & $5.21 \mathrm{a}$ \\
$\mathrm{HA}+\mathrm{K}$ & $3.06 \mathrm{~b}$ \\
$\mathrm{~K}+\mathrm{G}$ & $5.17 \mathrm{a}$ \\
$\mathrm{K}$ & $2.81 \mathrm{~b}$ \\
$\mathrm{HA}+\mathrm{K}+\mathrm{G}$ & $4.61 \mathrm{a}$ \\
$\mathrm{HA}+\mathrm{G}$ & $4.91 \mathrm{a}$ \\
$\mathrm{HA}$ & $1.90 \mathrm{~b}$ \\
US & $3.03 \mathrm{~b}$ \\
\hline
\end{tabular}



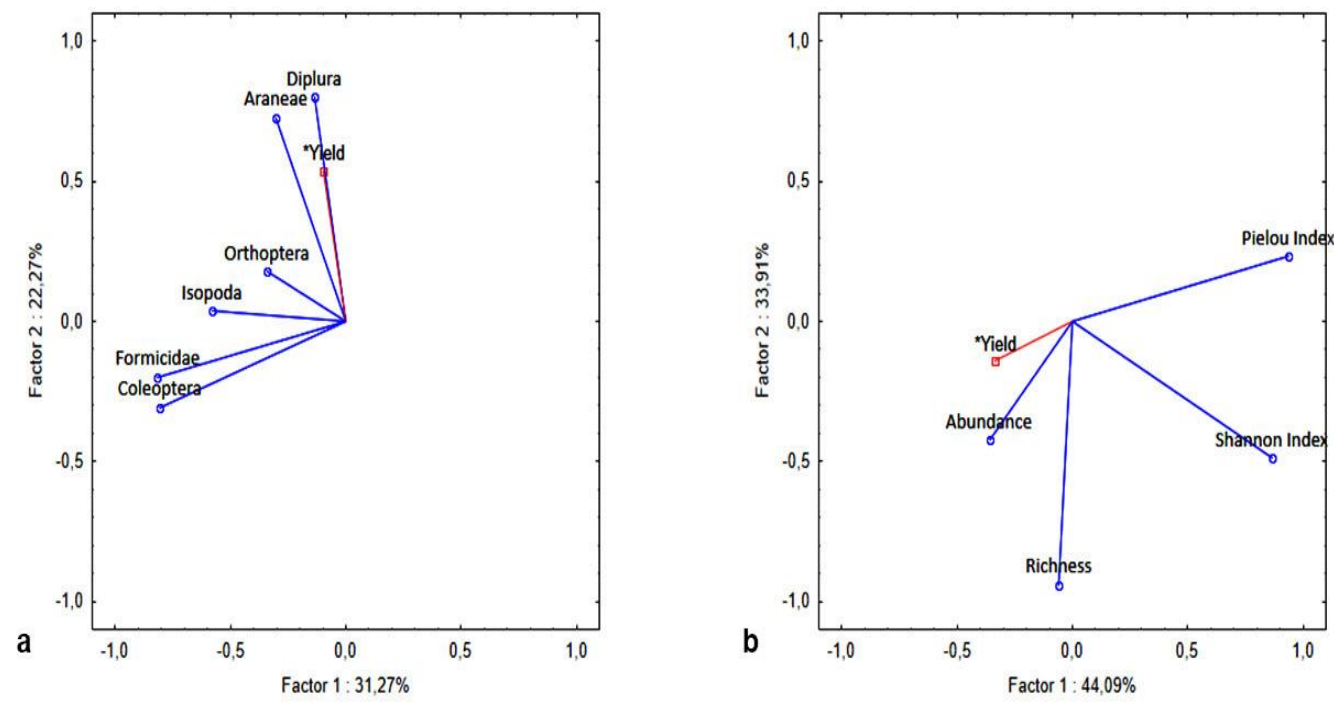

Fig 3. Principal component analysis (PCA) of the yield and the major groups of the soil fauna (a) and of yield and the ecological indexes and the abundance (b).

In this study, when $G$ and HA were applied separately, diversity was significantly higher than when they were applied together $(p<0.05)$. Some studies indicate that direct adverse effects on living organisms can be induced by humic substances (Bittner, 2006). In a maize cropping system in a tropical region, the diversity of the soil biota was modified by the presence of Leguminosae. Furthermore, this plant stimulated the development of organisms that can promote soil structure (Blanchart et al., 2006), and this may eliminate other taxa. Moura et al. (2015) argue that the use of some kind of leguminous plants can increase soil acidity and decrease the diversity of the fauna. These added factors may have maximized the negative effect on diversity when humic acid and gliricidia were applied together. De Bruyn (1999) highlight that low biological diversity is characteristic of a less resilient soil that is more vulnerable to perturbations. For Thakur et al. (2014), relationships between disturbance and diversity of soil fauna are dependent on the context. Thus, each case should be analysed carefully.

Franco et al. (2016) verified that the abundance of soil fauna had relationship with K. Sanabria et al. (2014) also found that land use influences the abundance of these organisms. Zhu and Zhu (2015) affirm that there is an association between different types of fertilization and the abundance of the soil fauna community. However, we did not confirm these findings in our research, because abundance did not show significant differences between treatments $(p>0.05)$. Three groups based on the shortest Euclidian distance were formed by cluster analysis. Treatments in the same group share the closest relationship, because according Lee et al. (2006), the distance represents the degree of association between treatments. Thus, the shorter this distance, the more intimate the association. Blanchart et al. (2006) showed that soil fauna was deeply affected by the introduction of a legume in maize crop areas, favouring the development of Isopoda and decreasing the size of the ant community. Although Isopoda are sensitive to soil alterations (Büchs, 2003), as are Formicidae (Andersen et al., 2002), no pattern was found here. Nevertheless, the grouping according to cluster analysis was consistent with the predominance of some taxa in different groups.

The maize grain yield was significantly higher in treatments that received gliricidia than in those that did not receive it ( $p$ $<0.05)$. This finding is consistent with that of Rao and
Mathuva (2000), who found that green manuring with gliricidia increased maize yield in an experiment conducted in Kenya. Kamara et al. (2000) attributed the increased maize yield to the presence of gliricidia because this legume has high nitrogen content and is fast decomposing, favouring crop development.

Ouédraogo et al. (2006) highlighted the positive effects of soil fauna on processes of fertility for plant growth. Shukla et al. (2016), for example, found that the ecosystem engineering activities of a species of ant enhance the yield of cereals. In the present study, however, we did not detect this association with maize yield. The only association we found by PCA between yield and groups of soil fauna occurred with Araneae. This finding does not corroborate with that of Paul et al. (2015), who found that higher maize grain yield in Kenya was related to a total exclusion of macrofauna. Rivers et al. (2016) explain that Araneae is a group of generalist predators, and these organisms can consume insect pests, contributing to reduced plant damage. For Sileshi and Mafongoya (2006), important functions such as predation may influence plant development, because they may prevent pest outbreaks and thus improve ecosystem sustainability. Since predator populations and prey populations are generally compatible (Moura et al., 2015), and pests may exist within the prey population, the activity of Araneae may reduce the amount of pests and favour increased maize yield.

For Zhu and Zhu (2015), edaphic fauna community indexes must be used in combination, for example, with productivity, in order to evaluate overall changes in soil fertility. In the present research, however, we did not find an association between yield and diversity indexes, although we observed a correlation between yield and fauna abundance. Increased yield associated with increased abundance may be related to the presence of invertebrates of different ecological functions (predators, engineers, decomposers) in the soil, even though there is no increase in biological diversity. For Kilowasid et al. (2012), this functional diversity improves ecosystem services, such as yield. Blanchart et al. (2006) affirm that a better use of biota resources may increase the functional properties of ecosystems and allow better agricultural productivity and sustainability. 


\section{Experimental design and maize yield}

The experiment was conducted at Brejo city (3038' south latitude and $42^{\circ} 58^{\prime}$ west longitude), Maranhão State, Brazil. This region has a humid tropical climate with $1200-1400 \mathrm{~mm}$ of average annual precipitation. The soil is an Arenic Hapludult (Soil Survey Staff, 2010), presenting a flat topography (slope $<1 \%$ ) and sandy textural class with the following characteristics: $\mathrm{pH} 4.4$ in $0.01 \mathrm{M} \mathrm{CaCl}_{2}$; organic $\mathrm{C}$ $15.5 \mathrm{~g} \mathrm{~kg}^{-1}$; potential acidity 4.7 , CEC $7.9 \mathrm{mmol}_{(\mathrm{c})} \mathrm{dm}^{-3}$; Ca 2.6, Mg 0.5, K $0.1 \mathrm{mmol}_{(\mathrm{c})} \mathrm{dm}^{-3}$; P $3.7 \mathrm{~g} \mathrm{dm}^{-3}$ (resin); and base saturation $40.2 \%$.

The experimental area was established in 2012 and consists of an alley crop system with Gliricidia (Gliricidia sepium), planted with an inter-row spacing of $4 \mathrm{~m}$ and an inter-plant spacing of $0.5 \mathrm{~m}$.

In January 2015, between the rows of the legume, the area was divided into 32 plots of $4 \times 10 \mathrm{~m}$ with seven treatments and the control, with four replicates $(R)$ in a randomized block design. The following treatments were performed: Gliricidia sepium - gliricidia (G), potassium (K), humic acid $(H A)$, humic acid + potassium $(H A+K)$, potassium + gliricidia $(K+G)$, humic acid + gliricidia $(H A+G)$, humic acid + potassium + gliricidia ( $H A+K+G$ ) and uncovered soil (US).

The pruning of the legume was carried out and the green matter was separated to be used in the treatments with gliricidia. In these treatments were applied $15 \mathrm{t} \mathrm{ha}^{-1}$ of biomass of the legume. In the treatments that received potassium were applied $78 \mathrm{~kg} \mathrm{ha}^{-1}$ of $\mathrm{KCl}$, while in treatments with humic acid were applied $500 / \mathrm{ha}^{-1}$ of this substance. All treatments received $120 \mathrm{~kg} \mathrm{ha}^{-1}$ of $\mathrm{P}_{2} \mathrm{O}_{5}, 60 \mathrm{~kg}$ $\mathrm{ha}^{-1}$ of $\mathrm{N}$ e $25 \mathrm{~kg} \mathrm{ha}^{-1}$ of $\mathrm{ZnSO}_{4}$. These doses were defined according to the result of the soil analysis.

Plants of maize (Zea mays L.), variety QPM BR 473, were cropped in each plot in March 2015 in a total area of 1.280 $\mathrm{m}^{2}$. At the phase of physiological maturity, ten cobs of each plot were collected, and the grains were extracted. The grain yield was estimated in $\mathrm{Mg}$ ha- ${ }^{1}$, from the total grain mass in each plot and the number of plants per hectare.

\section{Soil fauna}

Soil fauna was sampled using the pitfall trap method during a seven-day period in July 2015. These traps were made of plastic and were approximately $9 \mathrm{~cm}$ in height and $8 \mathrm{~cm}$ in diameter; these were allocated to the ground level. The samples were preserved in glasses with $200 \mathrm{~mL}$ of formaldehyde solution (4\%). The contents of the glasses was transferred to containers with $70 \%$ alcohol and properly identified.

In the laboratory, each sample was processed, separated and identified into order or family using a binocular microscope and taxonomic keys. Formicidae was considered separately from other Hymenoptera due to its ecological importance in the community.

Abundance, dominance and ecological indexes - richness, Shannon-Wiener diversity index $\left(H^{\prime}\right)$ and Pielou equitability index $\left(J^{\prime}\right)$ - were used for evaluation of soil fauna structure. Fauna abundance is calculated as the number of individuals per trap per day. Dominance is the number of individuals in a given taxon per trap per day. The richness is the number of groups that occur in the sample. The Shannon-Wiener index is calculated by the formula:

$$
H^{\prime}=-\sum_{i=1}^{s} p i \log _{2}(p i)
$$

where $p i=$ probability of a member of taxon $i$ occurring in a trap per day and $s=$ total number of taxa encountered in a trap per day. The Pielou evenness index indicates how individuals are distributed between the different taxa present in the sample. It is calculated as:

$$
J^{\prime}=\frac{H^{\prime}}{\log _{2}(s)}
$$

where $H^{\prime}$ is the Shannon index and $s$ is the number of groups present in a trap per day.

\section{Statistical analysis}

For statistical analysis, one-way ANOVA was conducted to determine the significance of the difference in means of soil fauna dominance, abundance, richness, Shannon-Wiener index, Pielou index and maize grain yield. Duncan's test was used to determine which differences were significant $(p<$ 0.05). Abundance data were transformed to meet the assumptions of normal distribution and homogeneity of variance. For cluster analyses, the Euclidean distance between the mean abundances of soil fauna groups was used as the measure of similarity to the areas by the Ward's method. The association between the maize grain yield and the major groups of soil fauna was analysed, as was the association between maize grain yield and the ecological indexes and abundance. For this investigation, principal component analysis (PCA) was used, after standardization of data. Statistica, version 7 (Statsoft Inc., 2004) was used for all analyses.

\section{Conclusion}

Our results show that treatment with humic acid and potassium caused the dominance of isopods, and this may have been favoured by the ecological function exerted by this group as detritivores. The dominance of ants was also related to potassium application, and this can be explained by the improvements in soil structure provided by this taxon and this nutrient. The lower diversity found in the treatment that combined humic acid and gliricidia may be explained by the potentiation of possible adverse effects that this legume and humic substances have on the structure of the soil fauna. Although studies have associated Formicidae with grain yield, in this study, the only taxon associated with yield was Araneae, who are predators that can reduce the pest population, favouring yield. Although the abundance of fauna did not show differences between treatments, it was related to yield. This finding may be due to the importance of the diversity of ecological functions performed by fauna rather than biological diversity. This study does not confirm the hypothesis that different soil fertilization regimes affect soil fauna, influencing the yield. Nevertheless, we confirm that yield may be increased with the presence of specific groups and with the abundance of soil fauna. Our results show the importance of soil fauna to agricultural sustainability, suggesting that these organisms can be used to evaluate soil quality in order to reach a higher yield. 


\section{Acknowledgements}

We would like to thank Fundação de Amparo à Pesquisa e ao Desenvolvimento Científico e Tecnológico do Maranhão FAPEMA.

\section{References}

Andersen AN, Hoffmann BD, Müller WJ, Griffiths AD (2002) Using ants as bioindicators in land management: simplifying assessment of ant community responses. J Appl Ecol. 39: 8-17.

Bahadur I, Meena VS, Kumar S (2014) Importance and application of potassic biofertilizer in Indian agriculture. Int Res J Biological Sci. 3: 80-85.

Bittner M (2006) Direct effects of humic substances on organisms. Masaryk university, Brno. Faculty of science. Thesis (PhD) - Centre for Environmental Chemistry and Ecotoxicology, Czech Republic. 31 pages.

Blanchart E, Villenave C, Viallatoux A, Barthès B, Girardin C, Azontonde A, Feller C (2006) Long-term effect of a legume cover crop (Mucuna pruriens var. utilis) on the communities of soil macrofauna and nematofauna, under maize cultivation, in southern Benin. Eur J Soil Biol. 42: S136-S144.

Büchs W (2003) Biodiversity and agri-environmental indicators - general scopes and skills with special reference to the habitat level. Agr Ecosyst Environ. 98: 3578.

Bünemann EK, Schwenke GD, Van Zwieten L (2006) Impact of agricultural inputs on soil organisms - a review. Aust J Soil Res. 44: 379-406.

Carrillo Y, Ball BA, Bradford MA, Jordan CF, Molina M (2011) Soil fauna alter the effects of litter composition on nitrogen cycling in a mineral soil. Soil Biol Biochem. 43: 1440-1449.

Cluzeau D, Guernion M, Chaussod R, Martin-Laurent F, Villenave C, Cortet J, Ruiz-Camacho N, Pernin C, Mateille T, Philippot L, Bellido A, Rougé L, Arrouays D, Bispo A, Pérès $G$ (2012) Integration of biodiversity in soil quality monitoring: Baselines for microbial and soil fauna parameters for different land-use types. Eur J Soil Biol. 49: 63-72.

Coleman DC, Crossley Jr DA, Hendrix PF (2004) Secondary production: Activities of heterotrophic organisms - the soil fauna. In: Fundamentals of soil ecology, 2nd edn. 79-185.

de Bruyn LAL (1999) Ants as bioindicators of soil function in rural environments. Agr Ecosyst Environ. 74: 425-441.

Errouissi F, Moussa-Machraoui SB, Ben-Hammouda M, Nouira S (2011) Soil invertebrates in durum wheat (Triticum durum L.) cropping system under Mediterranean semi arid conditions: A comparison between conventional and no-tillage management. Soil Till Res. 112: 122-132.

Franco ALC, Bartz MLC, Cherubin MR, Baretta D, Cerri CEP, Feigl BJ, Wall DH, Davies CA, Cerri CC (2016) Loss of soil (macro)fauna due to the expansion of Brazilian sugarcane acreage. Sci Total Environ. 563-564: 160-168.

Guimarães RML, Lamandé M, Munkholm LJ, Ball BC, Keller T (2017) Opportunities and future directions for visual soil evaluation methods in soil structure research. Soil Till Res. 173: 104-113.

Höfera H, Hanagarth W, Garcia M, Martius C, Franklin E, Römbke J, Beck L (2001) Structure and function of soil fauna communities in Amazonian anthropogenic and natural ecosystems. Eur J Soil Biol. 37: 229-235.
Hu F, Li HX, Wu SM (1997) Differentiation of soil fauna populations in conventional tillage and no-tillage red soil ecosystems. Pedosphere. 7: 339-348.

Huguenin MT, Leggett CG, Paterson RW (2006) Economic valuation of soil fauna. Eur J Soil Biol. 42: S16-S22.

Jiang M, Wang X, Liusui Y, Sun X, Zhao C, Liu H (2015) Diversity and abundance of soil animals as influenced by long-term fertilization in grey desert soil, China. Sustainability. 7: 10837-10853.

Kamara AY, Akobundu IO, Sanginga N, Jutzi SC (2000) Effect of mulch from selected multipurpose trees (MPTs) on growth, nitrogen nutrition and yield of maize (Zea mays L.). J Agron Crop Sci. 184: 73-80.

Kilowasid LMH, Syamsudin TS, Susilo FX, Sulistyawati E (2012) Ecological diversity of soil fauna as ecosystem engineers in small-holder cocoa plantation in south Konawe. J Trop Soils. 17: 173-180.

Lavelle P, Decaëns T, Aubert M, Barot S, Blouin M, Bureau F, Margerie P, Mora P, Rossi JP (2006) Soil invertebrates and ecosystem services. Eur J Soil Biol. 42: S3-S15.

Lee CS, Li XD, Shi WZ, Cheung SC, Thornton I (2006) Metal contamination in urban, suburban, and country park soils of Hong Kong: a study based on GIS and multivariate statistics. Sci Total Environ. 356: 45-61.

Moura EG, Aguiar ACF, Piedade AR, Rousseau GX (2015) Contribution of legume tree residues and macrofauna to the improvement of abiotic soil properties in the eastern Amazon. Appl Soil Ecol. 86: 91-99.

Ouédraogo E, Mando A, Brussaard L (2006) Soil macrofauna affect crop nitrogen and water use efficiencies in semiarid West Africa. Eur J Soil Biol. 42: S275-S277.

Paoletti MG, Bressan M, Edwards CA (1996) Soil invertebrates as bioindicators of human disturbance. Crit Rev Plant Sci. 15: 21-62.

Paul BK, Vanlauwe B, Hoogmoed $M$, Hurisso TT, Ndabamenye T, Terano Y, Six J, Ayuke FO, Pulleman MM (2015) Exclusion of soil macrofauna did not affect soil quality but increased crop yields in a sub-humid tropical maize-based system. Agr Ecosyst Environ. 208: 75-85.

Podgaiski LR, Quadros AF, Araujo, PB, Rodrigues GG (2011) Neotropical woodlice (Isopoda) colonizing leaf-litter of pioneer plants in a coal residue disposal environment. Rev Bras Cienc Solo. 35: 743-750.

Rao MR, Mathuva MN (2000) Legumes for improving maize yields and income in semi-arid Kenya. Agr Ecosyst Environ. 78: $123-137$

Rivers A, Barbercheck M, Govaerts B, Verhulst N (2016) Conservation agriculture affects arthropod community composition in a rainfed maize-wheat system in central Mexico. Appl Soil Ecol. 100: 81-90.

Sanabria C, Lavelle P, Fonte SJ (2014) Ants as indicators of soil-based ecosystem services in agroecosystems of the Colombian Llanos. Appl Soil Ecol. 84: 24-30.

Sanginga N, Mulongoy K, Swift ML (1992) Contribution of soil organisms to the sustainability and productivity cropping systems in the tropics. Agr Ecosyst Environ. 41: 135-152.

Shukla RK, Singh H, Rastogi N (2016) How effective are disturbance - tolerant, agroecosystem - nesting ant species in improving soil fertility and crop yield? Appl Soil Ecol. 108: 156-164.

Sileshi G, Mafongoya PL (2006) Long-term effects of improved legume fallows on soil invertebrate macrofauna and maize yield in eastern Zambia. Agr Ecosyst Environ. 115: 69-78. 
Siqueira GM, Silva EFF, Paz-Ferreiro J (2014) Land use intensification effects in soil arthropod community of an entisol in Pernambuco state, Brazil. Sci World J. 1-7.

Soil Survey Staff (2010) Keys to Soil Taxonomy. 11ed. USDANatural Resources Conservation Service, Washington, D.C., USA.

Statsoft Inc. (2004) Statistica, Version 7. Tusla, USA.

Tao H-H, Slade EM, Willis KJ, Caliman J-P, Snaddon JL (2016) Effects of soil management practices on soil fauna feeding activity in an Indonesian oil palm plantation. Agr Ecosyst Environ. 218: 133-140.

Thakur MP, Berg MP, Eisenhauer N, Van Langevelde F (2014) Disturbance-diversity relationships for soil fauna are explained by faunal community biomass in a salt marsh. Soil Biol Biochem. 78: 30-37.
Wong MH, Cheung KCC, Lan Y (1992) Factors related to the diversity and distribution of soil fauna on Gin Drinkers' Bay landfill, Hong Kong. Waste Manage Res. 10: 423-434.

Zhang W, Yuan S, Hu N, Lou Y, Wang S (2015) Predicting soil fauna effect on plant litter decomposition by using boosted regression trees. Soil Biol Biochem. 82: 81-86.

Zhu X, Zhu B (2015) Diversity and abundance of soil fauna as influenced by long-term fertilization in cropland of purple soil, China. Soil Till Res. 146: 39-46.

Zörb C, Senbayram M, Peiter E (2014) Potassium in agriculture - status and perspectives. J Plant Physiol. 171: 656-669. 